\title{
Review on Biomedical Applications of Marine Algae-Derived Biomaterials
}

\author{
Gayatree Nayak $^{1}$, Sanat Kumar Bhuyan,", Ruchi Bhuyan ${ }^{3}$, Akankshya Sahu ${ }^{1}$, \\ Ananya Kuanar ${ }^{1}$, Dattatreya Kar $^{3}$ \\ ${ }^{1}$ Centre for Biotechnology, Siksha 'O' Anusandhan University, Odisha, India \\ ${ }^{2}$ Institute of Dental Sciences, Siksha 'O' Anusandhan University, Odisha, India \\ ${ }^{3}$ Department of Medical Research, Health Science, IMS \& SUM Hospital, Siksha 'O' Anusandhan University, Odisha, India
}

Received September 24, 2021; Revised December 6, 2021; Accepted December 27, 2021

\section{Cite This Paper in the following Citation Styles}

(a): [1] Gayatree Nayak, Sanat Kumar Bhuyan, Ruchi Bhuyan, Akankshya Sahu, Ananya Kuanar, Dattatreya Kar, "Review on Biomedical Applications of Marine Algae-Derived Biomaterials," Universal Journal of Public Health, Vol. 10, No. 1, pp. 15 - 24, 2022. DOI: 10.13189/ujph.2022.100102.

(b): Gayatree Nayak, Sanat Kumar Bhuyan, Ruchi Bhuyan, Akankshya Sahu, Ananya Kuanar, Dattatreya Kar (2022). Review on Biomedical Applications of Marine Algae-Derived Biomaterials. Universal Journal of Public Health, 10(1), 15 - 24. DOI: 10.13189/ujph.2022.100102.

Copyright $\mathrm{C} 2022$ by authors, all rights reserved. Authors agree that this article remains permanently open access under the terms of the Creative Commons Attribution License 4.0 International License

\begin{abstract}
Marine algae have gained substantial attention from various scientific and commercial fields. The reason behind its importance is due to the rich source of bioactive compounds like proteins, carbohydrates, lipids, and other pigments. Marine algae-derived carrageenans polysaccharides are used in food, medicine, cosmetic items, gelling, emulsifying, and stabilizing agents. The carrageenan has also photoprotective activity as it protects against the UVB-induced apoptosis in $\mathrm{HaCaT}$ cells and inhibits skin aging and cancers. Marine algae-derived macromolecules including polysaccharides and proteins have anticoagulant and photoprotective activities. The marine algae used in health sector is not limited to a food supplement only, rather, the derivatives from it are increasingly used in the biomedical application too. Different biological activities of marine algae as immunomodulatory, anti-tumor, anti-viral, anti-cancer, anti-aging, anti-oxidant, and anti-diabetic are discussed in this review. This mini-review is comprehensively based on the bioactivities materials from brown, red, green, and blue-green algae used in various biomedical fields.
\end{abstract}

Keywords $\quad \begin{gathered}\text { Marine Algae, } \\ \text { Anti-Cancer, }\end{gathered}$
$\begin{aligned} & \text { Anti-Inflammatory, } \\ & \text { Polysaccharides, Photoprotective }\end{aligned}$

\section{Introduction}

Marine algae are virtuous bases of nutrient food sources and bioactive secondary metabolites used in the pharmaceutical industry, biomedical field and also have valuable outcomes on human health. Commonly marine algae are grown in salty or brackish water, sunlight and rocky places rather than sand shingle shores or in a littoral zone. Among all marine flora and fauna, algae are the fastest-growing organisms on Earth and can grow in tropical, cold-temperate, and Polar Regions. In general, marine algae are divided into two categories; the $1^{\text {st }}$ one is microalgae, which consist of dinoflagellates, blue-green algae, bacillariophyte, diatoms and the other is macroalgae (seaweeds), which contains green, brown, and red algae. Microalgae have potency to produced extremely high quantity of biomaterials that are used in biomedical fields. Nonetheless, red algae and their derived compounds have stronger biologically activity than other algae while seaweeds are the source of human food and gums. The Phycocolloides as like agar-agar, alginic acid and carrageenan are major componets of red and brown algae cell walls which are mostly used in pharmaceutical field [1]. The algae are available in both microscopic and macroscopic forms. The green microalgae are the largest group among all marine algae, distributed under Phylum Chlorophyta. The green microalgae like Spirulina, Arthrospira Platensis, Chlorella pyrenoidosa, 
Chlamydomonas reinhardtii, Cyanobacterium, and green motile algae are used as therapeutic drugs to treat various health issues and chronic diseases. The algae have a wide range of biologically active molecules with antimicrobial, antiviral, antifungal, antiallergic, anti-coagulant, anti-cancer, anti-fouling, anti-Inflammatory, and antioxidant properties [2]. The derivative compounds from marine algae replace the synthetic chemicals in drugs as these are seen more in peptides, amino acids, lipids, fatty acids, vitamins and minerals. Earlier reports suggested that the molecules like tannins, flavonoids, phenolic acid, bromophenols, and carotenoids are widely used in pharmaceuticals, cosmetics, and medical fields [3]. The phycoerythrobilin pigments found in red algae are used during the treatment of anti-inflammatory, neurodegenerative, gastric ulcers as well as cancer patients. It has also been used in various food and cosmetic industry [4]. In addition to, the marine algae-derived natural products protect cells by regulating the oxidative stress because it plays a crucial role in inflammatory, carcinogenic reactions. The algal-derived compounds are commonly natural products those have potential to use for anti-cancer and anti-inflammatory drugs. Some marine blue-green algae have cytotoxicity and immunosuppressive activity while red, brown algae also show photoprotective activity. Moreover, the cell wall of marine algae is composed of sulfated polysaccharides such as alginate, carrageenan, ulvan, fucoidan respectively. The algal-derived polysaccharides are biocompatible, multi-functional, therapeutical, promising bioactive material with a wide range of biomedical applications. Entry into pharmaceutical and cosmeceutical markets, the algae-based bioactivities seem to show a prominent future. Commercially, algae-based different bioactive products are widely used due to its efficacy and cost-effectivity but extraction methods need to be developed at the standardization level. Although, new technology is required for algae cultivation to achieve higher productivity and bioactive compounds. Moreover, different conventional procedures are used for breeding of algal strains for bioactive production which is not efficient. But the genetic transformation of algae is enhanced the production of biomaterials. Different biological investigations found that there is no clear evidence about bioactive compounds in algae also seen a lack of information on genomics and mechanism of gene regulations [5]. So that some major constitutions and limitations are hindering the development of algal research on biomedical applications. So it is necessary to do long-term research and confirm about it. In contrast, algae-based bioactive used in dermatology and cosmetic field, the accurate results to be known when it is sold in market and tested by people. From this review we explored the application of biomaterials and metabolites from various algae which are commonly used in pharmaceutical and biomedical fields [6].

\section{Methodology}

A basic and thorough overview of the literature surveyed to identify the biomedical applications of Marine algae-derived biomaterial was conducted till 2021. Many offline and online databases were taken into consideration. The review articles and research papers published by various reputed publishers such as Elsevier, Springer, and Taylor \& Francis imprints, Hindawi were considered as the data collection primary resource for this review article. Some online databases including NCBI, PubMed, Google Scholar, ProQuest, Scopus, and EBSCO were also accessed using keywords relating to the topic for data mining. The paid articles were accessed through the Centre Library facility of Siksha O Anusandhan University. The conference proceedings, magazines, WebPages, and book chapters were also reviewed and accessed as the other sources of literature to maximize the information about the current bottlenecks, the extent of research carried out, and the potential utility of the topic. In this review, we discussed about various bioactive materials of different marine algae. The current updates of marine algae-derived biomaterial are the main highlight of this review which will create a deep insight among the researchers about the updates and future research about the field of Marine Biotechnology.

\section{Nutritional Activity}

The Chlorella Vulgarisare (Chlorella) green algae from the phylum Chlorophyta contain protein approximately $50 \%-60 \%$ of its body weight. It is popular as a food supplement and widely used in the food industry due to its richness in protein and other essential amino acid. It also contains nutrients like $\beta$-1,3-glucan, $\beta$-carotene, vitamins B-complex and useful minerals like $\mathrm{K}^{+}, \mathrm{Na}^{+}, \mathrm{Mg}^{+2}, \mathrm{fe}$, and $\mathrm{ca}^{+2}$. Most importantly a nucleoprotein found in Chlorella Vulgaris is used as a growth factor and tissue repairing. Similarly, various other bioactive molecules found in marine algae are alginate in Eisenia Bicycles and Macrocystis Pyrifera; Agar in Gelidiella Acerosa; Retinol, Thiamine, Riboflavin, pyridoxine, B8, Folic Acid, Cobalamin, C, E in Spirulina Platensis; Vitamin C in Undaria Pinnatifida and Porphyra umbilicalis; Vitamin E in Nannochloropsis Oculate; Vitamin A, B1, B2, B12 and C in Senedesmus Quadricauda; and Vitamin A, B1, B2, B6, B8 in Chlorella Pyrenoidosa [7]. Other side seen that, microalgae can produce polyunsaturated fatty acids with multiple double bonds (PUFAs) as Phaeodactylum, Monodus, Nitzchia, and Isocrysis have been used to produce PUFAs while Crypthecodinium, Nannochloropis, and other algal species used in the food manufacturing industry[8].

Marine algae are commonly used in food industries to improve the quality of food products. In addition, algae are used in different meat products as pasty, steaks, frankfurters, sausages, and also used in fish foodstuffs, and oils for long-term storage. The algae are also used in cereal 
or crops, as pasta, flour,and bread. Although, algae are used for the fermentation of foods as cheese, cream, milk desserts, yogurt, cottage cheese, and processed cheese. The algae such as Enteromorpha Himanthalia elongata, Undaria pinnatifida, and porphyra umbilicalis have potency to maintain the anti-oxidant activity of meat and cereal products. Meat and its derived products are rich in proteins and vitamins but sometimes seen that lack of dietary fiber and an excess amount of sodium in meat, which can cause serious health hazards for humans [9]. The addition of algae Sea Spaghetti (Halomonas elongata), Wakame (Undaria pinnatifida), and Nori (Porphyra umbilicalis) in meat can increase $\mathrm{K}, \mathrm{Ca}, \mathrm{Mg}, \mathrm{Mn}$ and decrease salt content including fat and water binding properties. In addition, bread is a cereal-based product, to improve its quality green algae Ulva lactuca, and $2.5 \%$ of powdered Laminaria algae were added. Pasta is also a cereal-based product that has low protein and essential amino acids so high-protein additives are required to improve the quality of pasta. Studied that algae Undaria pinnatifida, rich in fucoxanthin was used $10 \%$ in pasta. In Indian brown algae, Sargassum marginatum was used in pasta for improved bio-functionality and quality. In Chinese, egg noodles were made by the addition of green algae Monostroma nitidum for better taste [10].

\section{Biological Activities of Marine Alga}

\subsection{Anti-Microbial Activity}

Marine algae have strong antibacterial, anti-fungal, and germicidal properties. The methanol extract of Sargassum Polycystum has strong antimicrobial activity. The methanol extract algae contained phenolic and alkaloid compounds which show antimicrobial activity [11]. The extract from Sargassum Polycystum has potentially inhibited the growth of bacteria like Escherichia.coli, Proteus vulgaris, Erwinia caratovora, and Klebsiella pneumonia. Similarly, the extracts from Sargassum Polycystum can prohibit the growth of fungi like Aspergillus niger, Rhizopus Stolonifer.The chloroform and ethanol extract of Sargassum tenerrimum has the highest antibacterial activity against Staphylococcus aureus. The c-lactone malyngolide 14 was identified from the dichloromethane of the blue-green alga Lyngbya majuscula which inhibits Mycobacterium smegmatis \& Streptococcus pyogenes. The Lyengaroside A 60 was identified from the green alga Codium iyengarii shows antibacterial activity. The main antimicrobial agent, which acts against the microbes of the blue-green algae is Lyngbya majuscule [12].

\subsection{Anti-Oxidant and Anti-Inflammatory Activity}

The carotenoids found in marine algae have antioxidant property which works as an immunity booster, wound healing, and other medical practices. The carotenoids from various marine algae have specialized health benefits as follows. The carotene isolated from Dunaliella salina shows both antioxidant and anti-inflammatory effects. Haematococcus pluvialis, Chlorella zofigiensis, and Chlorella vulgaris all have anti-oxidant, anti-inflammatory, and anti-tumor properties [13]. The antioxidant and anti-inflammatory activity are seen in zeaxanthin carotenoids that are produced from Dunaliella salina and Porphyridium cruentum as well as Chlorella protothecoids. Lutein has a specialized therapeutic role in age-related muscular degeneration (AMD), Atherosclerosis, retinal and neural damages. Although, Dunaliella salina, and Chlorella protothecoids derived carotenoids have anti-Oxidant and anti-Inflammatory activity. The lopophorins A 142 and B 143 were identified from the Caribbean brown alga Lobophora variegata (Dictyotales) which has anti-inflammatory activities and also potency inhibitors of tropical PMA-induced edema in the mouse ear. However, the microalgae Nannochloropsis Gaditana and Chlamydomonas debaryana produce oxylipins, which help to reduce inflammation [14].

\subsection{Anti-Cancer Activity}

The Violaxanthin that has anti-inflammatory and anti-cancer potency is extracted from Dunaliella tertiolecta and Chlorella ellipsoidea. Fucoxanthin which is found in Phaeodactylum tricornutum has antioxidant, anti-inflammatory as well as anti-cancerous properties. Curacin A 4 was identified from marine Cyanobacterium Lyngbya majuscule that is a new type of anticancer drug. The astaxanthin found in green microalgae Haematococcus Pluvialis, Chlorella zofingiensis, and Chlamydomonas nivalis has both anticancer \& antioxidant properties. Most importantly the b-carotene found in Dunaliella salinahas can specifically identify and destroy only neuroblastoma cells while unreflecting normal healthy cells, due to this ability, the Dunaliella has great importance in cancer therapy. The fucoxanthin molecules from diatom are also very effective against inflammation, obesity, diabetes, malaria, and treatment of cancer cells by pro-apoptotic process [15].

\subsection{Anti-Diabetic Activity}

The Dieckol molecules isolated from a brown alga called Ecklonia cava are anti-diabetic due to their hepatoprotective role and anticoagulant activities. The report found from in vivo testing that the fucosterol was identified from the brown alga Pelvetia siliquosa shows antidiabetic activity [16]. It was recommended to consume as a dietary supplement for the diabetic patient. Similarly, phlorotannins found in Ascophyllum nodosum can act against $\alpha$-glucosidase and $\alpha$-amylase that are helpful to digestion of starch and regulating blood sugar levels. The Ecklonia stolonifera species is used for anti-hypolipidemic activities due to the presence of molecules like 
phlorotannin anddeckel. These molecules can help in the reduction of LDL cholesterol level and triglyceride while the increase in HDL cholesterol [17].

\subsection{Anti-Ageing Activity}

In contrast, marine algae exposed to solar radiation can produce anti-aging and photoprotective molecules. All the molecules have the potential to reabsorb ultraviolet rays like UVA and UVB and can prevent the production of free radicals. Some algae are the major source of phenolic compounds with photoprotective Shinorine, Porphyra-334, polythene, eckstolonol, eckol, sargachromenol, tetraprenyltoluquinol chromane meroterpenoid, sctonemin, and sargaquinoic acid [18] are examples of active compounds in this category. Edible brown algae including Ecklonia cava, Eisenia bicyclis, and Ecklonia stolonifera have another phenolic ingredient called eckstolonol that helps protect skin's HaCat cells from damage caused by sunlight. The Eckstolonol (200M) in table 1 can repair UV-B-induced damage by activating the enzymes catalase and superoxide dismutase, which aids in the removal of excessive ROS [19].

\subsection{Anti-Viral Activity}

Marine algae-derived Phenolic compounds like phlorotannins and Phloroglucinol also have antiviral properties discussed in Table- 1 and chemical structures are in Figure-1. In vitro, the phlorotannins 8,8'-bieckol and $8,4^{\prime \prime \prime}$-dieckol can inhibit HIV-1 reverse transcriptase and protease. 6,6'-Bieckol, a Phloroglucinol compound derived from Ecklonia cava, can suppress HIV-1 by generating syncytia formation, lytic effects, and reducing viral p24 antigen synthesis in vitro. Additionally, it is also acting against the enzyme HIV-1 reverse transcriptase, an RNA-dependent DNA polymerase that helps in viral replication inside human cells without any cytotoxicity effect. The Halitunal 63 was identified from the marine alga Halimeda tuna that shows antiviral against murine coronavirus A59 in vitro [20].

\subsection{Anti-Fungal Activity}

Cyanobacteria are known as blue-green algae because it contains chlorophyll a and its related compounds. The cyanobacteria can produce secondary metabolism as Biologically active nitrogenous chemicals and cyclic polyethers [21]. An inhibitor of fungal plant diseases, Majuscuiamide C 16, was discovered in the blue-green algae Lyngby majuscula. The antifungal properties of dinoflagellates have been demonstrated by the discovery of Goniodomin A 23 from Goniodoma (Alexandrium) sp. and gambier acid from Gambierdiscus toxicus culture medium, respectively. The Capisterones A 67 and B 68 are identified from green alga Panicillus capitatus shows antifungal activity against the marine algal pathogen
Lindra thallasiae. The meroditerpenoid was identified from the brown alga Cystoseira tamariscifolia and characterized as methoxybifurcarenone 138. It has antifungal activity against 3 tomato pathogenic fungi and antibacterial activity against Agrobacterium tumefaciens and Escherichia coli [22].

\subsection{Immunosuppressive and Cytotoxicity Activity}

According to several investigations found that Lyngbya majuscula, a type of blue-green algae native to Venezuela, contains immunosuppressive lipoproteins known as microcolins A 17 and B 18. Murine mixed lymphocytes and murine P388 leukemia are both suppressed in vitro by microcolins [23]. Isorawsonol 30 is a phytochemical derived from the green alga Arrainvilla rawsonii that has anticancer, cytotoxicity, and immunosuppressive properties. In addition, the marine alga provided Communesins A 34, B 35, and Penostatins A 36, B 37, C 38, D 39, and E 40 which shows Immunosuppressive and cytotoxicity activity. The aplysin-9-ene 291, epiaplysinol 292 and debromoepiaplysinol 293, were identified from red alga Laurencia tristicha. Debromo-epiaplysinol 293 shows cytotoxicity to the HeLa cell line [24].

\subsection{Phytoprotective Activity of Marine Algae}

Different species of marine algae have various chemical compositions [25]. As red and brown algae are rich in sulfated polysaccharides such as carrageenan and fucoidan. The Carrageenans are thickening agents often used in food, medicine, cosmetic items, gelling, emulsifying, and stabilizing properties. Reported that, carrageenan bases skin products are antioxidant, detoxifying, cleansing, hydrating, and revitalizing activities. The carrageenan has also photoprotective activity as it protects against the UVB-induced apoptosis in $\mathrm{HaCaT}$ cells and inhibits the production of H2(ROS) because excess amounts of ROS can cause skin aging and cancers. The chemical structure of carrageenan is in Figure-1 [26].

Brown algae have sulfated polysaccharide called fucoidan, the biological activity of fucoidan is in Table-1 and the chemical structure is in Figure-1. Fucoidan, an antioxidant found in brown algae such as Ecklonia cava, Undaria pinnatifida, Costariacrostata, and Fucus evanescens, has photoprotective properties. Fucoidan's photoprotective properties were discovered in UVB-irradiated human skin fibroblasts. As the MMP-1 activity is suppressed by fucoidan's photoprotective properties. UV-irradiated human skin has collagen degradation and photoaging caused by MMP-1. Sulfated polysaccharides diminish NF-B expression by inhibiting NF-B, which in turn lowers MMP-1 levels. The photoprotective action of low-molecular-weight fucoidan is greater than that of UV filtering effects [27]. Aside from that, carotenoids protect photosynthetic organisms like algae and cyanobacteria from the sun's ultraviolet radiation. 
The carotenoid content in brown algae increased UVB exposure. The canaliculate plant Pelvetia Canilculata and the fucoxanthin of brown algae have photoprotective activity against UVB-induced photoaging. Photoprotective activities on Human dermal fibroblasts and hairless mice exposed to ionizing radiation have both shown the effect in vitro and in vivo. Fucoxanthin's photoprotective activity is based on ROS scavenging as a mode of action. There's a UV-sensitive gene called Filaggrin to inhibit wrinkle formation. Fucoxanthin can increase filaggrin promoter activity in UV-induced sunburns [28].

Different species of red algae and their biological activities are discussed below; As Solieria chordates have the absorption of UVB light and free radical scavengers. This plant, Porphyra umbilicalis, can prevent UV-ray damaged skin from erythema [29]. This plant, Porphyra yezoensis, can modify the viability of UVB-exposed $\mathrm{HaCaT}$ [30]. Solieria chordalis can protect synthetic chlorophyll solution from UVB, while Polysiphonia morrowii can shield $\mathrm{HaCaT}$ from UVB-induced cell damage. The HACT can be protected from UVB-induced cell damage using Chondracanthus tenellus, and can prevent $\mathrm{HaCaT}$ from UVB-induced cell damage are Bonnemaisonia hamifera, Lomentaria hakodatensis, Macrocystis pyrifera, and Porphyra columbina [31]. The following section discusses various brown algae species and their biological activity. When used as a UVB irradiated human keratinocyte model, Sargassum muticum inhibits wrinkle formation on UVB-induced mice in vivo and as a human skin cell model in vitro. $\mathrm{HaCaT}$ can be protected by Undaria crenata against UVB-induced cell damage. Several plants can shield the developing zebrafish embryo from UVB damage, including Lessonia vadose, Lessonia black, Ascophyllum nodosum, Saccharina latitissima, Fucus veneiculosus, Ecklonia maximum, and Durvillaea Antarctica [32].

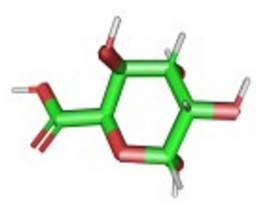

$$
\text { Alginate }
$$

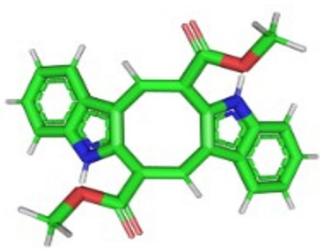

$$
\text { Caulerpin }
$$

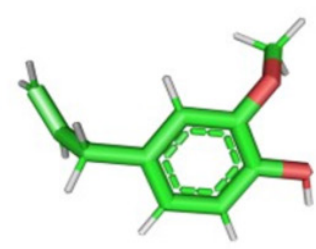

Eugenol

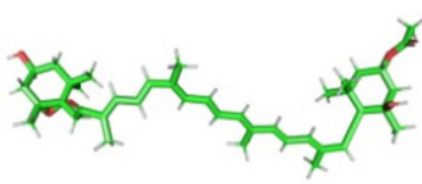

Fucoxanthins

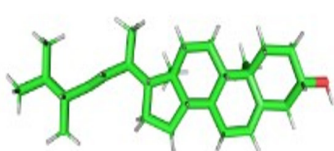

Brassicasterol

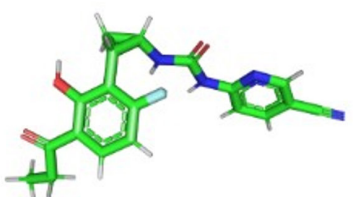

Carrageenan

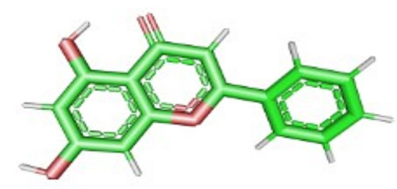

\section{Chrysin}

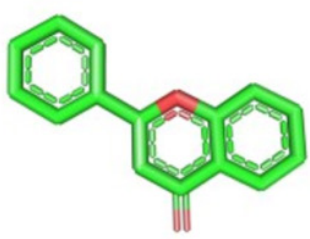

Flavonoid

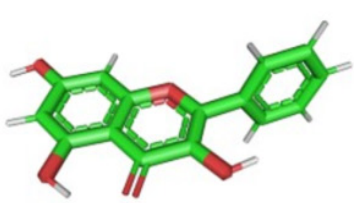

Galangin

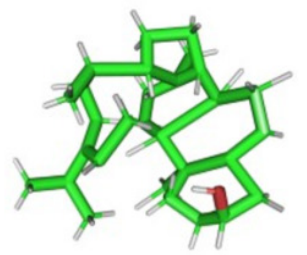

Fecosterol

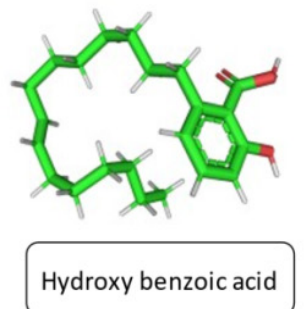




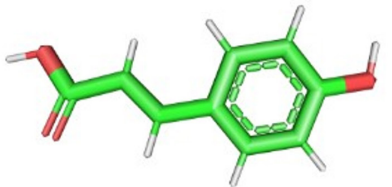

Hydroxy -cinnamic acid

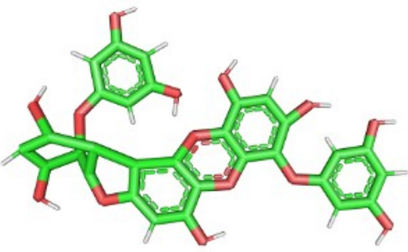

Phlorofucofuroeckol A

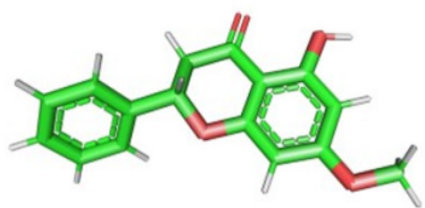

Pinostrobin

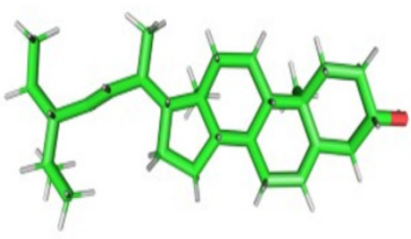

Stigmastero
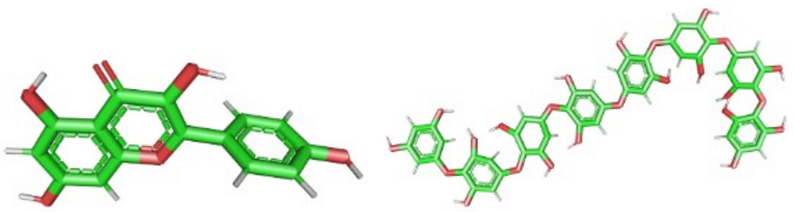

Kaempferol

Octaphlorethol A

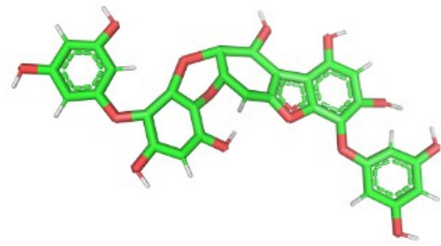

Phlorofucofuroeckol B

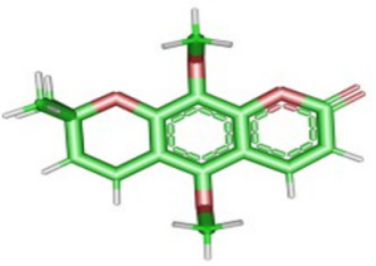

Racemosin A

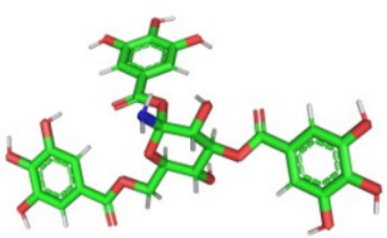

Tannin amine

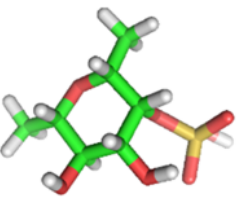

Fucoidan

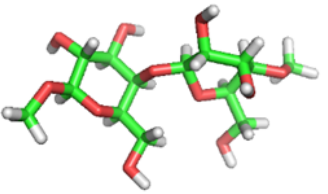

Galactan

Figure 1. The Algae derived chemical compounds with their 3D structures. 
Table 1. List of marine algae and their derived biological active compounds.

\begin{tabular}{|c|c|c|c|c|}
\hline Sl.no & Algae species & Compounds & Biological activity & References \\
\hline 1 & Ecklonia stolonifera & Phlorofucofuroeckol A \& B & Anti-inflammatory. & 34 \\
\hline 2 & Ecklonia. cava & Dieckol & Antitumor activity. & 35 \\
\hline 3 & Ishige foliacea & Octaphlorethol A & Anti-inflammatory. & 36 \\
\hline 4 & $\begin{array}{l}\text { Cystoseira mediterranea, } \\
\text { Pterocladiella capillacea }\end{array}$ & Flavonoids \& tannin & Antimicrobial. & 37 \\
\hline 5 & Cymopolia barbata & 3,7-hydroxycymopolone & Antimutagenic. & 38 \\
\hline 6 & Caulerpa racemosa & Racemosin A & Neuroprotective. & 39 \\
\hline 7 & Caulerpa racemosa & Caulerprenylols A & Antifungal. & 39 \\
\hline 8 & Ulva prolifera & pyrrolopipera-zine-2,5-dione & Antialgal. & 40 \\
\hline 9 & Cymopolia barbata & 7-Hydroxycymopolone (PBQ2) & Chemotherapeutic, Anticancer. & 40 \\
\hline 10 & $\begin{array}{l}\text { Caulerpa racemosa and Caulerpa } \\
\text { genus }\end{array}$ & Caulerpin & Anti-microbial. & 41 \\
\hline 11 & Brown algae & Alginate & Antitumour, Antifungal. & 42 \\
\hline 12 & Red algae & Carrageenan & Antioxidant, drug delivery. & 43 \\
\hline 13 & Green algae & Ulvan & Anti-microbial. & 43 \\
\hline 14 & $\begin{array}{l}\text { Adenocystis, } \\
\text { Utricularis, Grateloupia, } \\
\text { longifolia, Laminaria, guryanovae, } \\
\text { Codium, atlanticum, Monostroma } \\
\text { nitidum }\end{array}$ & Sulfated polysaccharides & Anti-HIV, Anti-tumor, Anti-coagulant. & 44 \\
\hline 15 & Arthrospira platensi & Spirulan & Anti-coagulant, anti-thrombic activity. & 45 \\
\hline 16 & $\begin{array}{l}\text { Isochrysis galbana; chaetoceros, } \\
\text { Skeletonema; Pavlova lutheri }\end{array}$ & $\begin{array}{l}\text { Brassica sterol, } \\
\text { Stigmasterol } \\
\end{array}$ & $\begin{array}{l}\text { Anti-bacterial, } \\
\text { Hypocholesterolemic. }\end{array}$ & 46 \\
\hline 17 & $\begin{array}{l}\text { Ecklonia stolonifera, } \\
\text { Ascophyllum nodosum, Ulva } \\
\text { lactuca, palmaria palmate, Alaria } \\
\text { esculenta. }\end{array}$ & Phlorotannin & $\begin{array}{l}\text { Anti-hypertension, Anti-cancer, } \\
\text { Anti-radio-protective, } \\
\text { Anti-photocarcinogenic, Anti-diabetic, } \\
\text { Anti-allergy, Anti-proliferative, } \\
\text { Anti-antiaging, Anti-Matrix } \\
\text { metalloproteinase. }\end{array}$ & 47 \\
\hline 18 & $\begin{array}{l}\text { Myagropsis, myagroides, Brown } \\
\text { algae }\end{array}$ & Fucoxanthins & $\begin{array}{l}\text { Anti-inflammatory, Anti -diabetic, } \\
\text { Anti-angiogenic. }\end{array}$ & 44 \\
\hline 19 & $\begin{array}{l}\text { Pelvetica siliquosa, Sargassum } \\
\text { Vulgare, Undaria, Pinnatifida, } \\
\text { Himanthalia, elongate, Chondrus, } \\
\text { Crispus, Porphyra, Ulva, and } \\
\text { Porphyra species. }\end{array}$ & Fecosterols & $\begin{array}{l}\text { Anti-cancer, Anti-diabetic, } \\
\text { Anti-fungicidal. }\end{array}$ & 49 \\
\hline 20 & Spirulina maxima & $\begin{array}{l}\text { Eugenol, } \\
\text { Hydroxy-cinnamic acids, } \\
\text { Hydroxy benzoic acids, } \\
\text { kaempferol, chrysin, galangin, } \\
\text { Pinostrobin }\end{array}$ & Antioxidant, Anti-hepatoprotective. & 50 \\
\hline
\end{tabular}

\subsection{Anti-Coagulant Activity}

The marine algae have anticoagulants properties because those contain sulphated glycosaminoglycans and include sulfated polysaccharides like heparin and heparan sulfate. In the algae group, the Phaeophyta (brown algae), Chlorophyta (green algae) and Rhodophyta (red algae) are the most aboudant, among them anticoagulant polysaccharides have been isolated from red and brown algae are carrageenans and fucoidans, respectively. The homogenous polysaccharides of galactose or fucose are commonly found in red and brown algae. However, there was no report on green algae containing anticoagulant polysaccharides. But reported that Codium fragile ssp. tomentose, of green algae, has excellent anticoagulant polysaccharides. Recently reported that green algae are heterogeneous polysaccharides and homogenous galactan. Algal anticoagulant polysaccharides are used for antithrombin III (AT III) and heparin cofactor II (HC II) that are endogenous inhibitors, called SERPIN. In contrast, some algal anticoagulant polysaccharides are used directly to inhibit fibrin polymerization or thrombin activity without potentiating AT III and HC II. Algal anticoagulant polysaccharides can activate the fibrinolysis system and modulate endothelial cell functions. The bioactive compounds of marine algae show anti-platelet and 
anticoagulant proteins and fibrinolytic enzymes [33]. The marine algae derived polysaccharides and proteins have attracted great attention in various health sectors due to their anticoagulant activity.

\section{Conclusions}

Marine algae have potential source of bioactive substances in the medical and cosmetic fields. Marine algae-derived compounds have unique chemical structures with excellent biological activities and are also "natural and healthy" with nontoxic materials. Different species of marine algae have several properties without any toxicity and a good safety profile. Marine algae are produced a wide variety of biological active compounds with significant effects. The marine algae-derived molecules are better than synthetic compounds used in various food and medicinal production. It is used in skincare products also acts as photoprotection. From the past few decades, the studies on the potential use of marine algae in human health benefits have been increased the importance in various sectors. Microalgae-derived compounds have high demand in pharmaceutical, nutraceutical, cosmetic, animal feed, biological waste treatment, and other multifunctional activities due to the richness in bioactive molecules. Microalgae have the potential activity to treat cancer, inflammation, Alzheimer's, CVDs, malaria, leishmaniasis, $\mathrm{TB}$, HIV etc through majour sources of natural bioactive compounds like carotenoids, PUFAs, proteins, polysaccharides, glycolipids. It was also found that different biologically active compounds from marine algae-like aflatoxins, dolostatins, majusculamides, carotenes have an excellent health benefit. So that researchers should be exploring the potential use of bioactive compounds from marine algae in advanced biomedical applications and field of biotechnology. Algae-based biomaterials show a prominent future in pharmaceutic and cosmeceutic fields. But still there is no clear evidence found about bioactive compounds in algae so needs to long term research to achieve major compounds of algae and that can be used in biomedical applications, the accurate results to be known when it is sold in market and tested by people.

\section{Acknowledgments}

The authors are grateful to Prof (Dr). Sudam Chandra Si, Dean and Prof (Dr). Manoj Ranjan Nayak, President, Centre of Biotechnology, Siksha O Anusandhan University, for providing all facilities.

\section{Financial Discloser}

The authors have no affiliation with any organization with a direct or indirect financial interest in the subject matter discussed in the manuscript. The following authors have affiliations with organizations with a direct or indirect financial interest in the subject matter discussed in the manuscript.

\section{REFERENCES}

[1] Pujiastuti DY., Ghoyatul Amin MN., Alamsjah MA., Hsu JL,"Marine organisms as potential sources of bioactive peptides that inhibit the activity of angiotensin I-converting enzyme: a review,"International journal of Molecular science, vol.24, no.14, pp.2541. 2019. DOI: https://doi.org/10.3390/molecules24142541

[2] Lauritano C., Helland K., Riccio G., Andersen JH., Ianora A., Hansen EH, "Lysophosphatidylcholines and chlorophyll-derived molecules from the diatom Cylindrotheca closterium with anti-inflammatory activity," Marine drugs, vol.18, no.3, pp.166. 2020. DOI: https://doi.org/10.3390/md18030166

[3] Fertah M., Belfkira A., Taourirte M., Brouillette F, "Extraction and characterization of sodium alginate from Moroccan Laminaria digitata brown seaweed," Arabian Journal of Chemistry, vol. 10, no.2, pp.S3707-S3714. 2017. DOI:https://doi.org/10.1016/j.arabjc.2014.05.003

[4] Ermakova S., Kusaykin M., Trincone A., Tatiana Z, "Are multifunctional marine polysaccharides a myth or reality?," Frontiers in chemistry, vol.3, pp.39. 2015. DOI: https://doi.org/10.3389/fchem.2015.00039

[5] Hafting J T., Craigie J S., Stengel D B., Loureiro R R., Buschmann A H., Yarish C. Critchley, A. T, "Prospects and challenges for industrial production of seaweed bioactives," Journal of Phycology,Vol.51, no.5, pp. 821-837. 2015. DOI: https://doi.org/10.1111/jpy.12326.

[6] Wang HM., Li XC., Lee DJ., Chang JS, "Potential biomedical applications of marine algae," Bioresource technology, vol.244, pp.1407-15, 2017. DOI: https://doi.org/10.1016/j.biortech.2017.05.198.

[7] Wang L., Park YJ., Jeon YJ., Ryu B, "Bioactivities of the edible brown seaweed, Undaria pinnatifida: A review," Aquaculture, vol.495, pp.873-880, 2018. DOI: https://doi.org/10.1016/j.aquaculture.2018.06.079

[8] Ávila-Román J., Talero E., de Los Reyes C., García-Mauriño S., Motilva V, "Microalgae-derived oxylipins decrease inflammatory mediators by regulating the subcellular location of NFKB and PPAR- $\gamma$," Pharmacological research, vol.128, pp.220-30. 2018. DOI: https://doi.org/10.1016/j.phrs.2017.10.009.

[9] Ścieszka S., and Klewicka E, "Algae in food: A general review," Critical reviews in food science and nutrition, vol.59, no.21, pp.3538-3547. 2019. DOI: https://doi.org/10.1080/10408398.2018.1496319.

[10] Pina-Perez M C., A Rivas., A Martınez., and D Rodrigo, "Antimicrobial potential of macro and microalgae against pathogenic and spoilage microorganisms in food," Food Chemistry, vol.235, pp.34-44. 2017. DOI: https://doi.org/10.1016/j.foodchem.2017.05.033. 
[11] Singkoh MF., Katili DY., Rumondor MJ, "Phytochemical screening and antibacterial activity of brown algae (Padina australis) from Atep Oki Coast, East Lembean of Minahasa Regency, "Aquaculture, Aquarium, Conservation \& Legislation, vol.14, no.1, pp.455-61. 2021.

[12] Achmad H., Huldani H., Feby Ramadhany Y, "Antimicrobial Activity and Sulfated Polysaccharides Antibiofilms in Marine Algae Against Dental Plaque Bacteria: A Literature Review," A multifaceted review journal in the field of pharmacy, 2020.

[13] Bule MH., Ahmed I., Maqbool F., Bilal M., Iqbal HM, "Microalgae as a source of high-value bioactive compounds," Frontiers In Bioscience, vol.10, pp.197-216. 2018.

[14] Gong M., Bassi A., "Carotenoids from microalgae: A review of recent developments," Biotechnology advances, vol.34, no.8, pp.1396-1412. 2016. DOI: 10.1016/j.biotechadv.2016.10.005.

[15] Li R., Wu H., Zhuo WW., Mao Q.F., Lan H., Zhang Y., Hua $\mathrm{S}$, "Astaxanthin normalizes epigenetic modifications of bovine somatic cell cloned embryos and decreases the generation of lipid peroxidation," Reproduction in Domestic Animals, vol.50, no.5, pp.793-799. 2015. DOI: https://doi.org/10.1111/rda.12589.

[16] Rosa GP., Tavares WR., Sousa P., Seca AM., Pinto DC, "Seaweed secondary metabolites with beneficial health effects: An overview of successes in in vivo studies and clinical trials," Marine drugs, vol.18, no.1, pp.8. 2020. DOI: https://doi.org/10.3390/md18010008.

[17] Yu Y., Wang L., Fu X., Wang L., Fu X., Yang M., Han Z., Mou H., Jeon YJ, "Anti-oxidant and anti-inflammatory activities of ultrasonic-assistant extracted polyphenol-rich compounds from Sargassum muticum," Journal of Oceanology and Limnology, vol.37, no.3, pp.836-847. 2019. DOI: https://doi.org/10.1007/s00343-019-8138-5.

[18] Carson MA., Clarke SA, "Bioactive compounds from marine organisms: Potential for bone growth and healing," Marine drugs, vol.16, no.9, pp.340. 2018. DOI: https://doi.org/10.3390/md16090340.

[19] Verdes A., Holford M, "Beach to Bench to Bedside: Marine Invertebrate Biochemical Adaptations and Their Applications in Biotechnology and Biomedicine," Marine Organisms as Model Systems in Biology and Medicine, pp.359-76. 2018 .

[20] Parimala S, Begum A, "A review on anti hiv agents from marine sources," World Journal of Pharmaceutical Research, vol.8, no. 6, pp.235-241, 2019. DOI: 10.20959/wjpr20196-14716.

[21] Srivastava A., Mishra V, "Marine peptides act as novel chemotherapeutic agent," Journal of Microbiology \& Experimentation, vol.6, no.6, pp.267-70. 2018.

[22] Al-Enazi NM., Awaad AS., Alqasoumi SI., Alwethairi MF, "Biological activities of the red algae Galaxaura rugosa and Liagora hawaiiana butters," Saudi Pharmaceutical Journal, vol.26, no.1, pp.25-32. 2018. DOI: https://doi.org/10.1016/ j.jsps.2017.11.003.

[23] Gogineni V., Hamann MT, "Marine natural product peptides with therapeutic potential: Chemistry, biosynthesis, and pharmacology," Biochimica et Biophysica Acta
(BBA)-General Subjects, vol.1862, no.1, pp.81-196. 2018. DOI: https://doi.org/10.1016/j.bbagen.2017.08.014.

[24] Liu S., Su M., Song SJ., Jung J H," Marine-derived Penicillium species as producers of cytotoxic metabolites," Marine drugs, vol.15, no.10, pp.329. 2017. DOI: https://doi.org/10.3390/md15100329.

[25] Olasehinde TA., Mabinya LV., Olaniran AO., Okoh AI. "Chemical characterization, antioxidant properties, cholinesterase inhibitory and anti-amyloidogenic activities of sulfated polysaccharides from some seaweeds," Bioactive Carbohydrates and Dietary Fibre, vol.18, pp.100182. 2019. DOI: https://doi.org/10.1016/j.bcdf.2019 .100182

[26] Karim N., Khan I., Khan W., Khan I., Khan A., Halim SA., Khan H., Hussain J., Al-Harrasi A, "Anti-nociceptive and anti-inflammatory activities of asparacosin a involve selective cyclooxygenase 2 and inflammatory cytokines inhibition: an in-vitro, in-vivo, and in-silico approach," Frontiers in immunology, vol.10, pp.581. 2019. DOI: https://doi.org/10.3389/fimmu.2019.00581

[27] Pangestuti R., Siahaan EA., Kim SK., "Photoprotective substances derived from marine algae," Marine drugs, vol.16, no.11, pp.399. 2018. DOI: https://doi.org/10.3390/ md16110399.

[28] Jing R., Guo K., Zhong Y., Wang L., Zhao J., Gao B., Ye Z., Chen Y., Li X., Xu N., Xuan X, "Protective effects of fucoidan purified from Undaria pinnatifida against UV-irradiated skin photoaging," Annals of translational medicine, vol.14. 2021. DOI: https://dx.doi.org/10.21037/a tm-21-3668.

[29] Kim YI., OhWS., Song PH., Yun S., KwonYS., Lee YJ., KuSK., Song CH., Oh TH., "Anti-photoaging effects of low molecular-weight fucoidan on ultraviolet B-irradiated mice," Marine drugs, vol.16, no. 8, pp.286. 2018. DOI: https://doi.org/10.3390/md16080286.

[30] Matsui M., Tanaka K., Higashiguchi N., Okawa H., Yamada Y., Tanaka K., Taira S., Aoyama T., Takanishi M., Natsume C., Takakura Y., "Protective and therapeutic effects of fucoxanthin against sunburn caused by UV irradiation," Journal of pharmacological sciences, vol.132, no.1, pp.55-64. 2016. DOI: https://doi.org/10.1016/j.jphs.2 016.08 .004

[31] Álvarez-Gómez F., Korbee N., Casas-Arrojo V., Abdala-Díaz RT., Figueroa FL, "UV photoprotection, cytotoxicity and immunology capacity of red algae extracts," Molecules, vol.24, no.2, pp.341. 2019. DOI: https://doi.org /10.3390/molecules24020341.

[32] Pangestuti R., Siahaan EA., Kim SK, "Photoprotective substances derived from marine algae," Marine drugs, vol.16, no.11, pp.399. 2018. DOI: https://doi.org/10.3390/ md16110399.

[33] Mercurio DG., Wagemaker TAL., Alves VM., Benevenuto CG., Gaspar LR., Campos PM, "In vivo photoprotective effects of cosmetic formulations containing UV filters, vitamins, Ginkgo biloba and red algae extracts," Journal of Photochemistry and Photobiology B: Biology, vol.153, pp.121-126. 2015. DOI:https://doi.org/10.1016/j.jphotobio 1.2015 .09 .016

[34] Lee YJ., Park JH., Park SA., Joo NR., Lee BH., Lee KB., Oh SM, "Dieckol or phlorofucofuroeckol extracted from 
Ecklonia cava suppresses lipopolysaccharide-mediated human breast cancer cell migration and invasion," Journal of Applied Phycology, vol.32, no.1, pp.631-40. 2020. DOI: https://doi.org/10.1007/s10811-019-01899-2.

[35] Shrestha S., Zhang W., and Smid SD, "Phlorotannins: A review on biosynthesis, chemistry and bioactivity," Food Bioscience, vol.39, p.100832. 2020. DOI: https://doi.org/10.1016/j.fbio.2020.100832.

[36] Ha JW., Song H., Hong SS., Boo YC, "Marine alga ecklonia cava extract and dieckol attenuate prostaglandin $\mathrm{E} 2$ production in $\mathrm{HaCaT}$ keratinocytes exposed to airborne particulate matter," Antioxidants, vol.8, no.6, pp.190. 2019. DOI: https://doi.org/10.3390/antiox8060190.

[37] Kumar MS., Patravale VB, "Marine - derived Potential Anti - inflammatory Agents," Encyclopedia of Marine Biotechnology, vol.4, pp.2585-605. 2020. DOI: https://doi.org/10.1002/9781119143802.ch116.

[38] El-Din SMM., El-Ahwany AM, "Bioactivity and phytochemical constituents of marine red seaweeds (Jania rubens, Corallina mediterranea and Pterocladia capillacea)," Journal of Taibah University for Science, Vol.10, no.4, pp.471-484. 2016. DOI: https://doi.org/10.1016/j.jtusci.20 15.06.004.

[39] Shah SA., Bungau S., Si Y., Xu H., Rahman M., Behl T., Gitea D., Pavel FM., Corb Aron RA., Pasca B., Nemeth S. "Chemically diverse and biologically active secondary metabolites from marine Phylum chlorophyta," Marine Drugs, vol.18, no.10, pp.493. 2020. DOI:https://doi.org/10 $.3390 / \mathrm{md} 18100493$.

[40] Eismann AI., Reis RP., da Silva AF., Cavalcanti DN, "Ulva spp. carotenoids: Responses to environmental conditions," Algal Research, vol.48, pp.101916. 2020. DOI: https://doi.org/10.1016/j.algal.2020.101916.

[41] Khan K., Tareen AK., Iqbal M., Mahmood A., Shi Z., Yin J., Qing D., Ma C., Zhang H, "Recent development in Graphdiyne and its derivative materials for novel biomedical applications," Journal of Materials Chemistry B, 2021.

[42] Cantarino SJ., Coutinho R., Soares AR., Duarte HM., Martinez ST, "Microwave irradiation is a suitable method for caulerpin extraction from the green algae Caulerpa racemosa (Chlorophyta, Caulerpaceae),"Natural Product Research, vol.20, pp.1-5. 2020. DOI: https://doi.org/10.10 $80 / 14786419.2020 .1844684$.

[43] Manivasagan P., Oh J, "Marine polysaccharide-based nanomaterials as a novel source of nanobiotechnological applications" International journal of biological macromolecules, vol.82, pp.315-327. 2016. DOI: https://doi.org/10.1016/j.ijbiomac.2015.10.081.

[44] Zhong B., Robinson NA., Warner RD., Barrow CJ., Dunshea FR., Suleria HA, "Lc-esi-qtof-ms/ms characterization of seaweed phenolics and their antioxidant potential," Marine drugs, vol.18, no.6, pp.331. 2020. DOI: https://doi.org/10.3390/md18060331.

[45] Lauritano C., Helland K., Riccio G., Andersen JH., Ianora A., Hansen EH, "Lysophosphatidylcholines and chlorophyll-derived molecules from the diatom Cylindrotheca closterium with anti-inflammatory activity," Marine drugs, vol.18,no.3, pp.166. 2020. DOI: https://doi.org/10.3390/md18030166

[46] Miguel SP., Ribeiro MP., Otero A., Coutinho P, "Application of microalgae and microalgal bioactive compounds in skin regeneration," Algal Research, vol.58, pp.102395. 2021. DOI:https://doi.org/10.1016/j.algal.2021 .102395 .

[47] Sanjeewa K KA., Kim EA., Son KT., Jeon YJ, "Bioactive properties and potentials cosmeceutical applications of phlorotannins isolated from brown seaweeds: A review," Journal of Photochemistry and Photobiology B: Biology, vol.162, pp.100-105. 2016. DOI: https://doi.org/10.1016/j.j photobiol.2016.06.027.

[48] Verma ML., Chandel A eds, "Biotechnological production of bioactive compounds," Elsevier. 2019.

[49] Sudhakar MP., Kumar BR., Mathimani T., Arunkumar K, "A review on bioenergy and bioactive compounds from microalgae and macroalgae-sustainable energy perspective," Journal of Cleaner Production, vol.228, pp.1320-33. 2019. DOI: https://doi.org/10.1016/j.jclepro.2019.04.287.

[50] Tuvikene R, "Carrageenans, In Handbook of Hydrocolloids," Woodhead Publishing, pp.767-804. 2021. DOI: https://doi.org/10.1016/B978-0-12-820104-6.000061. 